DOI: https://doi.org/10.32839/2304-5809/2021-8-96-25

УДК 658.14

Кнір М.О., Ковальчук І.С.

Київський національний університет імені Тараса Шевченка

\title{
ЕМІСІЙНА ПОЛІТИКА КОРПОРАЦІЙ
}

\begin{abstract}
Анотація. Розглядається місце емісійної політики у системі фінансово-економічного забезпечення корпоративного управління. Представлено механізм фрінансово-економічної підтримки корпоративного управління. Розглянуто механізм формування емісійної політики компанії, а також особливості реалізації емісійних заходів на кожному з ії етапів. Проаналізовано активність корпорацій у збільшенні статутного капіталу на фрондовому ринку та відстежено механізм реалізації фінансових інструментів, що використовуються при реалізації заходів емісійної політики, а також цілей, які акціонерне товариство переслідуе при їх реалізації. описано. Розвиток ринкових відносин у компанії призвів до появи низки нових економічних об'єктів обліку та аналізу. Одним з них є капітал компанії як найважливіша економічна категорія і особливо власний капітал. Фінансова політика компанії є ключовим моментом для збільшення темпів їі економічного потенціалу в умовах ринкової економіки з їі жорсткою конкуренцією.
\end{abstract}

Ключові слова: емісійна політика, емітент, фондовий ринок, корпорації, фрінансово-економічний механізм, ліверидж.

Knir Mariya, Kovalchuk Ihor Taras Shevchenko National University of Kyiv

\section{EMISSION POLICY OF CORPORATIONS}

Summary. In the modern economy, the securities market is one of the main mechanisms for the accumulation and redistribution of investment capital and allows enterprises in industrialized countries to effectively solve their capital formation and management tasks by means of issuing operations. The development of issuing operations has not reached this level in Ukraine. Ukrainian companies, which have serious financing needs, however, rarely enter the organized securities market. Moreover, the process of making financing decisions by the management of Ukrainian companies is very different from that of developed countries. Therefore, the development of Ukrainian corporations and, eventually, Ukrainian economy, is impossible without the entry of domestic and foreign equity and debt capital markets. Thus, the development of the securities market becomes vitally important for the formation of Ukraine as a developed industrial power and the resolution of strategic tasks facing the country, such as doubling GDP, carrying out social reforms or modernizing fixed assets, is only possible with a steadily developing stock market and the effective functioning of national enterprises as its main participants. In this regard, the problem of efficient issuance operations on the capital market and the development of the company's issuance policy is very relevant for domestic corporations. The relevance of the topic is determined by favorable changes in the Ukrainian economy: the growth of production and business expansion, consolidation of enterprises, the emergence of new emission instruments expanding the range of investors, the establishment of the securities market and its legislative framework. At the same time, it should be noted that there are "separate" gaps in the study of the problems of issuance operations. Thus, there are very few works in modern domestic scientific literature devoted to making financing decisions and capital structure management in practice, and there are no works on financial engineering (construction of securities) in Ukrainian conditions, the study of market rate behavior and liquidity indicators of shares after the initial offering.

Keywords: issuance policy, issuer, stock market, corporations, financial and economic mechanism, leverage.

$\Pi^{2}$ остановка проблеми. Глобальна фpiнансова криза завдала великого удару по розвитку підприємницького сектору усього світу та української економіки, зокрема. За умов фрінансової кризи в Україні, зменшення обсягів реалізації продукції і прибутків підприємств, обмеження можливостей залучення кредитних банківських ресурсів та слабкості розвитку фондового ринку, особливого значення набуває необхідність вивчення проблем емісійної політики, також акціонерного капіталу та дивідендної політики, які мають на меті випуск різноманітних цінних паперів та корпоративних прав. Вони слугують джерелом поповнення власного і позикового капіталу підприемства в необхідній кількості.

Крім того, у нашій країні відбувається становлення ринкової системи, створюються нові підприємства акціонерного типу. Їх створення, а також нормальне фонкціонування неможливо уявити без формування достатнього обсягу капіталу, нестача якого викликає необхідність здійснювати пошук додаткових джерел фінансування, використовувати для цього як власні, так і позикові фінансові ресурси. У такий спосіб, особливого значення набуває проблематика аналізу емісійної політики корпорацій.

Аналіз останніх досліджень і публікацій. Теоретичною основою роботи стали нормативноправові акти, що регулюють діяльність комерщійних банків. Окрім нормативних джерел, використовувались підручники О. Шестака, А. Журавльова, В. Бочарова, Г. Кравцової, П. Мамановича та інших авторів, довідкова та інша інформація.

Широкий спектр навчальної літератури з таких дисциплін, як фінансовий менеджмент, економічний аналіз, чинні закони та правила, низка підручників, що містять аналітичні матеріали та дані, a також Інтернет-індрормаційні ресурси широко використовувались у написанні даної статті.

Мета роботи - запропонувати шляхи підвищення ефрективності емісійної політики організації, розглянути суть емісійної політики компанії 


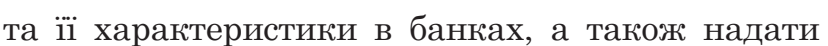
рекомендащії щодо вдосконалення операщій з щінними паперами власного випуску в організації.

Виклад основного матеріалу. Через високу вартість залучення власного капіталу із зовнішніх джерел цілі емісії повинні бути достатньо значними з точки зору стратегічного розвитку компанії та можливості значного збільшення їі ринкової вартості в найближчий період. Основними цілями, які компанія очолюе, використовуючи це джерело формування власного капіталу, є:

- реальні інвестиції, пов'язані із галузевою (підгалузевою) та регіональною диверсифікацією виробничої діяльності (створення мережі нових філій, дочірніх підприемств, нових високопродуктивних галузей тощо);

- необхідність суттево вдосконалити структуру зайнятого капіталу (збільшення частки в статутному капіталі з метою підвищення рівня фрінансової стійкості;

- забезпечення більш високого рівня власної кредитоспроможності, тим самим зменшуючи витрати на залучення позикового капіталу;

- посилення едректу левериджу тощо;

- планові поглинання інших компаній з метою досягнення синергетичного ефректу (участь у приватизації державних підприемств третіх сторін також може розглядатися як можливість їх поглинання, якщо це забезпечуе придбання контрольного пакету або переважної частки в статутному капіталі);

- інші цілі, що вимагають швидкого накопичення значних сум власного капіталу.

Визначення обсягу емісії. Визначаючи обсяг, необхідно враховувати розраховану раніше потребу в отриманні власних фрінансових ресурсів із зовнішніх джерел.

Оцінка вартості залученого капіталу. Відповідно до принципів такого оцінювання воно проводиться за двома параметрами:

- очікувана сума дивідендів (визначаеться на основі обраного типу дивідендної політики);

- вартість випуску акцій та розміщення акцій (зменшена до середньорічного розміру).

Систему КУ, яка спрямована на розв'язання завдань виключно фрінансових та економічних напрямків діяльності, прийнято називати системою фінансово-економічного забезпечення корпорації. Система фрінансово-економічного забезпечення корпорації - це механізм фрінансовоекономічного забезпечення КУ - переслідує дві основні цілі, що доповнюють основну ціль КУ:

1) максимізацію поточної вартості одніеї акції в акціонерному капіталі;

2) дотримання ліквідності, тобто здатності корпорації виконувати свої внутрішні та зовнішні фонансові зобов'язання.

Механізм фрінансово-економічного забезпечення КУ $є$ системою основних елементів, які регулюють процеси капіталізації як основи створення та розвитку корпорації.

Корпорації насамперед відомі як найпоширеніші та найчисленніші форми утворення суб'єктів господарювання у світовій економіці. Саме діяльність корпорацій $є$ визначальною для розвитку економічних систем провідних країн світу та у міжнародній економіці. Отже, діяльність корпорацій стає основою розвитку економіки України. Значна кількість суб'єктів господарської діяльності фрункціонуе саме у формі акціонерних товариств (АТ). Так, у США на початку 10-х років XXI ст. корпорації становили близько 23\% усіх суб'єктів господарювання. В Україні кількість АТ пості зростає, і сьогодні вже становить понад 35 тис. Вклад вітчизняного корпоративного сектора в промислове виробництво досягає майже $70 \%$.

В економічно розвинутих країнах світу значна частина населення $є$ акщіонерами різноманітних корпорацій. Як відомо 3 економічної літератури, акціонером у Швеції є кожний другий громадянин, у США та Англії - більше ніж кожний п'ятий, в Японії - кожний сьомий. Унаслідок приватизаційних процесів в Україні, акціонерами в нашій країні є достатньо велика частина населення - близько 20 млн. громадян, що становить більше 30\% населення [3, с. 10].

При деяких відмінностях у правових базах розвинутих країн корпоративна форма має спільні ознаки. Так, економісти i правники в США в основу поняття «корпорація» покладають правову фрорму бізнесу, відокремленого від конкретних осіб, які ним володіють. При цьому поняття "корпорація» не стосується підприемств, які утворюються за рахунок об'єднання осіб, а не капіталів. Для участі в товариствах, утворених за рахунок об'єднання капіталів, необхідно зробити майновий внесок, тоді як інші об'єднання передбачають особисту участь в управлінні, представництві, здійсненні функщій 3 виробничо-господарської діяльності. Корпорація має право юридичної особи і їй найбільше відповідає форома акціонерного товариства [6, с. 14-15].

Концентрація та централізація капіталу $є$ вихідною базою для формування корпоративних структур. С. Росс дає таке визначення цього поняття: «Корпорація - це бізнес, заснований як окрема юридична особа, що складається з одного чи більше фрізичних чи юридичних осіб» $[6$, с. 31$]$. Як зазначає профресор Мочерний С.В., корпорація - це акціонерна компанія, у якій на основі централізації капіталів і заощаджень найманих працівників здійснюеться колективне привласнення результатів виробничої діяльності залежно від величини отриманих на внесені кошти акцій [8, с. 172].

При усіх відмінностях у правових базах розвинутих країн основна розмежувальна лінія між корпоративним i некорпоративним (сектором пролягає у відділенні фрункщій розпорядження й обмеженій відповідальності. Так, організаційно-правова база Німеччини та Франщії до корпоративного (сектора відносить АТ та товариства 3 обмеженою відповідальністю. У США до корпоративного сектора економіки належать тільки корпорації.

В українській правовій базі поняття корпорації істотно відрізняється від загальноприйнятого у світовій практиці. Відповідно до Закону України «Про підприемства в Україні», корпорації - це договірні об'єднання, створені на основі поєднання виробничих, наукових та комерційних інтересів, 3 делегуванням окремих повноважень централізованого: регулювання діяльності кожного з учасників [4]. Суть такої фрорми об'єднань та повноваження її учасників зрозуміти повністю, виходячи $з$ такого визначення, досить важко. Тому 
доцільно дотримуватись загальноприйнятого в економічній літературі визначення КУ та його об'єктів, якими є АТ.

Основна відмінність корпорацій від інших форм організування бізнесу полягає у тому, що вона існуе незалежно від іiі власників. Корпорація має право залучати капітал у грошовій форомі від свого імені, не покладаючи на своїх акціонерів додаткової відповідальності. Таким чином, основні відмінні ознаки корпорацій - наявність спільного капіталу, розділеного на визначену кількість рівних частин (акцій), а також принцип розмежування відповідальності корпораціі та їі власників (акціонерів - юридичних та opiзичних осіб).

В основу реалізащії управління будь-якими фінансово-економічними напрямками діяльності корпорацій покладено систему КУ. КУ поєднує в собі норми законодавства, внутрішні нормативні документи та практику господарювання в державному та недержавному секторі, що дає можливість реалізовувати доступ ВАТ до фоондів фрінансового ринку, ефективно здійснювати господарську діяльність i, в такий спосіб, продовжуючи своє фрункціонування, нагромаджувати курсову вартість корпорації через підвищення вартості акцій і захищаючи при цьому інтереси акціонерів і суспільства в цілому.

Під ефрективним корпоративним управлінням розуміеться управління, яке дає змогу корпораціям реалізовувати свої потенціальні можливості щодо залучення інвестицій, раціонально використовувати отримані кошти, а також забезпечувати зростання вартості капіталу акціонерів [8, с. 10].

1. Аналіз емісії корпоративних цінних паперів у попередніх періодах.

Метою цього етапу $є$ визначення обсягів та форм залучення капіталу корпорацією у попередніх періодах та ефрективності його використання. Окремо на цьому сталі досліджуеться них паперів, динаміка залучення позикового капіталу та емісія боргових корпоративних інвестиційних вкладень, ймовірність росту ефректу фрінансового лівериджу із залученням додаткового капіталу.

2. Визначення можливостей ефективного розміщення емісії корпоративних цінних паперів.

Цей етап включає:

- всебічний попередній аналіз кон'юнктури фондового ринку. Результатом проведення такого аналізу буде визначення рівня чутливості реагування фондового ринку на нову емісію корпоративних цінних паперів, визначення груп потенційних акціонерів та оцінка потенціалу поглинання емітованих цінних паперів;

- оцінка інвестиційної привабливості власних корпоративних цінних паперів порівняно 3 аналогічними видами щінних паперів, що обертаються на ринку.

Можливості едрективного розміщення цінних паперів проводиться з урахуванням результатів першого етапу, вже існуючого досвіду емісії цінних паперів, досвіду працівників корпорації стосовно проведення емісії. Важливим результатом цього етапу формування емісійної політики корпорації повинен стати висновок щодо визначення найбільш привабливого виду корпоративних емісійних цінних паперів відповідно до загальної мети емісї.

3. Визначення цілей емісії корпоративних цінних паперів.

Окрім загальної мети емісійної політики корпорації, що полягає у залученні на фрінансовому ринку необхідних фрінансових ресурсів у мінімально можливі терміни та задоволенні потреби корпоращії в придбанні необхідних активів і оптимізації структури капіталу з позиції забезпечення умов едрективного його використання, будь-яка. Емісія корпоративних цінних паперів передбачає використання залучених фрінансових ресурсів 3 певною метою. Такими цілями емісійної політики можуть бути:

1. Формування структури власності:

a) формування статутного фонду корпорації;

б) покращання структури капіталу (нарощування частки власного капіталу (статутного фонду) та скорочення залученого з метою підвищення фрінансової стійкості корпорації).

2. Додаткове залучення фрінансових ресурсів:

а) здійснення реальних інвестицій (здійснення капітальних вкладень, відкриття нових структурних підрозділів корпорації, дочірніх структур, диверсифікація виробництва);

б) планування поглинання або участі у приватизації інших підприемств;

в) підвищення рівня кредитоспроможності та едректу фрінансового лівериджу;

г) інші цілі, що вимагають швидкої акумуляції капіталу.

\section{4. Визначення обсягу емісії.}

Визначення обсягу емісії здійснюеться відповідно до цілей (З етап) та можливостей ефективного розміщення емісії (2 етап). Таким чином, існуе два основні чинники, що визначають обсяги емісії корпоративних цінних паперів:

1) вплив зі сторони зовнішнього середовища (ємність ринку, величина попиту на окремі види корпоративних цінних паперів, платоспроможність цільових груп потенційних інвесторів);

2) вплив зі сторони корпорації (реальна потреба у фрінансових ресурсах, законодавче обмеження обсягів емісії окремих видів корпоративних цінних паперів, рівень фрінансової стійкості корпорації та максимальне значення едекту фрінансового лівериджу).

5. Визначення виду, номіналу та кількості корпоративних цінних паперів, що емітуються.

Вибір виду корпоративних цінних паперів, що емітуються, здійснюеться відповідно до цілі емісії (встановлюеться на 3 етапі), а також обсягу фінансових ресурсів, у яких існує потреба (4 етап). Якщо ціллю емісії є нарощування чи формування статутного фонду, то единим фінансовим інструментом можуть бути акщії (та похідні цінні папери). Однак для реалізації цієї цілі необхідно визначити. вид (або види) акцій, можливості використання похідних цінних паперів, що дасть можливість збільшити суму залученого капіталу або зробити доступнішими акції та привабливішими умови їх придбання для потенційних акціонерів.

6. Формування ефективних умов залучення капіталу.

До найважливіших умов залучення капіталу із використанням корпоративних цінних паперів відносяться: 
1) термін обороту цінних паперів.

Цей етап включає оптимізацію терміну обороту цінних паперів з метою максимального збігу із терміном реалізації інвестиційного проекту, для реалізації якого здійснюеться емісія;

2) визначення планового рівня дивідендів чи відсотків за користування (при використанні боргових цінних паперів).

\section{7. Оцінка вартості залученого капіталу.}

Ця оцінка здійснюеться за двома параметрами:

а) рівень дивідендів чи відсотків за користування;

б) рівень витрат, пов'язаних з емісією та розміщенням корпоративних цінних паперів.

Оцінка здійснюеться з урахуванням умов залучення капіталу (6 етап), виду та кількості емітованих цінних паперів (5 етап) та обсягу емісії (4 етап).

8. Визначення ефективних форм андеррайтингу.

Для швидкого та едрективного розміщення емітованих цінних паперів необхідно визначити доцільність використання фрінансових посередників (андеррайтерів) У разі прийняття позитивного рішення необхідно визначити ціну початкового продажу, розмір комісійної винагороди, забезпечити регулювання обсягів продажу емітованих цінних паперів залежно від термінів, на які існує необхідність у фрінансових ресурсах [1, с. 519].

Окрім того, для визначення ефрективних фором андеррайтингу враховуються існуючий досвід використання андеррайтингу (1 етап), дослідження можливостей ефективного розміщення цінних паперів, проведене на 2 етапі, вид, кількість цінних паперів (встановлюеться на 5 етапі) та загальний обсяг емісії (4 етап) - емісійних корпоративних цінних паперів повинні виступати показники рентабельності та обороту залученого капіталу. Використання залученого капіталу із використанням емісійних корпоративних цінних паперів проводиться відповідно до цілей емісії, розроблених на 3 етапі.

9. Забезпечення свосчасних розрахунків за емісійними корпоративними цінними паперами.

Реалізащія заходів емісійної політики повинна ставити за мету підвищення інвестиційної привабливості корпорації (їі цінних паперів) шляхом максимізації вартості. акцій та дивідендів за ними, а також повних та своєчасних виплат за іншими корпоративними цінними паперами. Заходи корпоративної емісійної політики не повинні призводити до втрати довіри потенційних акціонерів та інших груп інвесторів до корпорації та зниження інвестиційної привабливості її цін- них паперів. 3 цією метою можуть створюватись резервні фонди за окремими найбільш ризиковими інвестиційними. проектами, фрінансування яких здійснюеться шляхом емісії боргових цінних паперів. Платежі за обслуговуванням корпоративних емісійних боргових цінних паперів повинні заключатись в платіжний календар корпорації і жорстко контролюватись у процесі моніторингу поточної фрінансової діяльності.

Висновки 3 проведеного дослідження. Емісійна політика $є$ частиною акціонерної політики компанії. Метою емісійної політики компанії є пошук зовнішніх джерел фрінансування. Інші сорери емісійної політики - це перерозподіл активів, збільшення статутного капіталу за рахунок залучення нових акціонерів, розширення ринку своїх акцій, збільшення статутного капіталу компанії, а також позикового капіталу, фінансування зростання довгострокових активів та забезпечення руху оборотного капіталу.

Основною метою емісійної політики $є$ якнайшвидше залучення необхідного обсягу власних фінансових ресурсів на ринок цінних паперів. Враховуючи сдрормульовану мету, емісійна політика компанії $е$ частиною загальної політики формування власних фрінансових ресурсів, яка полягає у забезпеченні залучення необхідної суми коштів шляхом випуску та розміщення власних акцій на ринку цінних паперів.

Отже, розробка ефрективної емісійної політики компанії охоплює наступні етапи. Слід підкреслити, що залучення додаткового капіталу за допомогою нової емісії акцій - це тривалий і витратний процес. Тому цим джерелом залучення фінансових ресурсів користуються лише великі акціонерні товариства, які мають достатні фрінансові ресурси та загальновідомі на фондовому ринку.

Повноцінне забезпечення фрінансовими ресурсами дає змогу підвищувати здатність корпорації приймати ризики, пов'язані 3 іiі довготривалим розвитком: реалізацію нових проектів, проведення і наукових досліджень, збільшення частки ринку. Доступ через корпоративні цінні папери до фінансових ресурсів потрібно використовувати активніше, оскільки економіка України все ще залишається здебільшого дефіцитною (за майновими правами на перспективні об'єкти власності, нерухомість тощо) [3, с. 136]. Окрім того, корпоративна форма фрінансово-господарської діяльності дає можливість використовувати найширший спектр фінансових інструментів (використання похідних цінних паперів) для залучення основного та додаткового капіталу.

\section{Список літератури:}

1. Бланк И.А. Основы финансового менеджмента. Т. 1. Киев : Ника Центр, 1999. 592 с. (Серия «Библиотека фринансового менеджера». Вып. 3).

2. Економічний словник-довідник / За ред. С.В. Мочерного. Київ : Феміна, 1995. 368 с.

3. Свтушевський В.А. Основи корпоративного управління : навч. посіб. Київ : Знання-Прес, 2002. 317 с.

4. Про підприемства в Україні : Закон України від 27.03.1991 № 887-XII (втратив чинність) // База даних «Законодавство України» / ВР України. URL: http://zakon3.rada.gov.ua/laws/show/887-12

5. Олексіенко Л.М. Фінансова стратегія виходу підприемств на ринок цінних паперів. Фінанси Украӥни. 2001. С. 136.

6. Положення Державної комісії з цінних паперів та фондового ринку «Про порядок реєстрації випуску облігацій підприемств та інформації про їх емісію» М 07. 0198 від 12 лютого 1998 року.

7. Росс С., Вестерфилд Р., Джордан Б. Основы корпоративных финансов / пер. с англ. Москва : Лаборатория Базовых Знаний, 2000. 718 с.

8. Чечетов М., Мендрул О. Корпоративне управління в умовах економічної трансформації. Еконоліка України. 2001. № 4. C. 10. 


\section{References:}

1. Blank I.A. (Ed.) (1991) Osnovy fynansovoho menedzhmenta [Fundamentals of financial management], vol. 1. Kyiv: Nika Center. (in Russian)

2. Mochernyi S.V. (1995) Ekonomichnyi slovnyk-dovidnyk [Economic Dictionary-Reference]. Kyiv. (in Ukrainian)

3. Ievtushevskyi V.A. (2002) Osnovy korporatyunoho upravlinnia [Fundamentals of corporate governance]. Kyiv. (in Ukrainian)

4. Pro pidpryyemstva v Ukrayini: Zakon Ukrayiny [Law of Ukraine on enterprises in Ukraine № 887-XII] (1991, March, 27). (in Ukrainian)

5. Oleksiienko L.M. (2001) Finansova stratehiia vykhodu pidpryiemstv na rynok tsinnykh paperiv [Financial strategy of enterprises entering the securities market]. Finansy Ukrainy [Finance of Ukraine]. Moscow, p. 136. (in Ukrainian)

6. Polozhennia Derzhavnoi komisii z tsinnykh paperiv ta fondovoho rynku "Pro poriadok reiestratsii vypusku oblihatsii pidpryiemstv ta informatsii pro yikh emisiiu» [Regulations of the State Commission on Securities and Stock Market "On the procedure for registration of the issue of corporate bonds and information on their issue"] № 07. 0198 (1998, February, 12).

7. Ross S., Vesterfild R., Dzhordan B. (2000) Osnovyi korporativnih finansov [Fundamentals of corporate finance] (Trans.). Moscow: Laboratory of Basic Knowledge, p. 718. (in Ukrainian)

8. Chechetov M., Mendrul O. (2001) Korporatyvne upravlinnia v umovakh ekonomichnoi transformatsii [Corporate governance in terms of economic transformation]. Ekonomika Ukrainy [Economy of Ukraine], p. 10. (in Ukrainian) 